\title{
Intake and digestive kinetics of leaf and stem fractions
}

\author{
JAMES B. LAMB, DON C. ADAMS, TERRY J. KLOPFENSTEIN, RICK J. GRANT, PHILLIP L. SIMS, \\ LARRY M. WHITE, AND STEVEN S. WALLER
}

\begin{abstract}
Lamb is former Research Associate and Adams is Professor, Univ. of Nebraska-Lincoln, Institute of Agr. and Natural Resources, West Central Res. and Extension Center, 461 West University Drive, North Platte, Neb. 69101; Klopfenstein and Grant are Professor and Associate Professor, Dept. of Animal Science Univ. of Nebraska-Lincoln 68583; Sims and White are Research Leader and retired, USDA-ARS, Southern Plains Res. Station, Woodward, Okla. 73801; Waller is Professor Dept. of Agronomy Univ. of Nebraska-Lincoln 68583. Correspondence should be addressed: Don Adams, West Central Research and Extension Center, North Platte, Nebr. 69101.
\end{abstract}

\section{Abstract}

Ruminally fistulated steers were used in a $4 \times 4$ Latin square to test effects of immature (vegetative) and mature (post reproductive) leaf and stem fractions from subirrigated meadow hay on organic matter intake (OMI), organic matter digestibility (OMD), and digestive kinetics. Hay was harvested 1 June (immature) and 1 October (mature), chopped into 3- to 5-cm lengths, then separated into leaf and stem fractions using a modified Clipper Cleaner Model Super 69D. Steers were provided ad libitum access to fractions and supplemented with urea so that diets were iso-nitrogenous. Particulate passage was determined using Yb labeled large hay particles $[\geq 1.7-\mathrm{mm}$ screen] and Er labeled small particles $[<1.7-\mathrm{mm}$ and $\geq 0.212-\mathrm{mm}$ screen]. Samples were collected from the rumen, omasum, feces, and un-masticated diets for particle size determination. Particle size was determined using wet sieving techniques. Voluntary OMI of immature fractions $\left(15.4 \mathrm{~g} \mathrm{~kg}^{-1} \mathrm{BW}\right)$ was greater $(\mathrm{P}<0.05)$ than mature fractions $\left(12.5 \mathrm{~g} \mathrm{~kg}^{-1} \mathrm{BW}\right)$. Within maturity OMI and OMD of leaves and stems were similar. Immature fractions had greater $(P<$ 0.05) OMD (63.2\%) than mature fractions $(55.7 \%)$. Large and small particle passage rates were faster $(P<0.05)$ for immature fractions $\left[3.2 \%\right.$ hour $^{-1}$ (large) and $4.3 \%$ hour $^{-1}$ (small)] than mature [ $2.3 \%$ hour $^{-1}$ (large) and $2.9 \%$ hour $^{-1}$ (small)]. Critical particle size for ruminal escape was $\leq 1.18 \mathrm{~mm}$ for both leaves and stems regardless of maturity. Differences in OMI and OMD between immature and mature fractions were explained by changes in structural components of the cell wall that made particles more resistant to mechanical and microbial breakdown.

Key Words: digestibility, retention, particle size, rumen, feces, omasum

Forage maturity influences quality of forages (Streeter et al. 1968, Nichols 1989). A decline in forage quality can be attributed largely to changes in the leaf and stem ratios (Nelson and Moser 1994) and associated decline in stem quality. Forage intake is associated with the proportion of indigestible fiber and the length of time retained in the rumen (Ulyatt et al. 1986). Particle size and passage rate were inversely related (Ehle 1984). Poppi et al. (1985) and Hendricksen et al. (1981) found differences in voluntary intake of leaves and stems. They attributed changes in intake

This manuscript has been assigned Journal Series No. 13080 , Agr. Res. Division, Univ. of Nebraska.

Manuscript accepted 15 Feb. 01

\section{Resumen}

Se utilizaron novillos fistulados ruminalmente en un diseño de Cuadro Latino 4 × 4 para probar los efectos de las fracciones inmaduras (vegetativo) y maduras (post-reproductiva) de hoja y tallo de heno producido en praderas subirrigadas en el consumo de materia orgánica (CMO), digestibilidad de la materia orgánica (DMO) y cinética digestiva. El heno se cosechó el 1 de Junio (inmaduro) y el 1 de Octubre (maduro), se pico en trozos de 3 a 5 cm de longitud y luego se separo en hojas y tallos utilizando un Cortador Limpiador modelo Super 69D modificado. A los novillos se les permitió acceso ad libitum heno de las fracciones de hoja y tallo y se suplementaron con urea de tal forma que las dietas fueron iso-nitrogenadas. El paso de las partículas fue determinado utilizando partículas grandes de heno marcadas con $\mathrm{Yb}$ [malla $\geq 1.7-\mathrm{mm}$ ] y partículas chicas marcadas con $\mathrm{Er}$ [malla $<1.7-\mathrm{mm}$ y $\geq 0.212-\mathrm{mm}$ ). Para determinar el tamaño de partícula se colectaron muestras del rumen, omaso, heces fecales y dietas sin masticar. El tamaño de partícula se determino usando la técnica de cribado húmedo. El consumo voluntario de materia orgánica de fracciones inmaduras $\left(15.4 \mathrm{~g} \mathrm{~kg}^{-1} \mathrm{PV}\right)$ fue mayor $(P<0.05)$ que el de las fracciones maduras $\left(12.5 \mathrm{~g} \mathrm{~kg}^{-1}\right.$ PV). Dentro de madurez, el consumo de materia orgánica y la digestibilidad de la materia orgánica de hojas y tallos fueron similares. Las fracciones inmaduras tuvieron una mayor $(P<$ $0.05)$ DMO $(63.2 \%)$ que las fracciones maduras $(55.7 \%)$. Las tasas de paso fueron mas rápidas $(P<0.05)$ para las fracciones inmaduras [3.2\% hora $^{-1}$ (grandes) y $4.3 \%$ hora $^{-1}$ (pequeñas)] que para las maduras $\left[\left(2.3 \%\right.\right.$ hora $^{-1}$ (grandes) y $2.9 \%$ hora $^{-1}$ (pequeñas)]. El tamaño de partícula crítico para le escape ruminal fue de $\leq 1.18 \mathrm{~mm}$, tanto para tallos como para hojas, sin importar la madurez. Las diferencias en el CMO y la DMO entre las fracciones maduras e inmaduras fueron explicadas por cambios en los componentes estructurales de la pared celular que hicieron a las partículas mas resistentes a el desdoblamiento mecánico y microbial

to differences in ruminal retention times. Longer retention times were associated with fractions that were more resistant to mechanical and microbial breakdown. Leaves within maturity were less resistant to particle size reduction than stems, thus passage rate of leaves was faster than stems.

Limited information is available on the effects of individual leaf or stem fractions on intake, digestibility, and rumen kinetics in beef cattle. Our objectives were to determine effect of plant maturity on voluntary intake, digestibility, digestive kinetics, and escape protein of leaf and stem fractions of meadow hay. 


\section{Materials and Methods}

\section{Treatments and Feeding}

Four ruminally cannulated steers (avg body weight $=418 \mathrm{~kg}$ ) fitted with $10.2-\mathrm{cm}$ i.d. ruminal cannulae were used in a $4 \times 4$ Latin square to determine effects of immature and mature leaf and stem hay fractions on organic matter intake (OMI), organic matter digestibility (OMD), and ruminal retention time, passage rate, and particle size distribution. Steers were fistulated and housed at the University of Nebraska-Lincoln Animal Science building under conditions described in the animal use protocols approved by the Institutional Animal Care and Use Committee at the University of Nebraska. Leaf and stem hay fractions were harvested at the University of Nebraska Gudmundsen Sandhills Laboratory (elevation $1,073 \mathrm{~m}, 42^{\circ} 05^{\prime} \mathrm{N}$ Lat, $101^{\circ} 26^{\prime} \mathrm{W}$ Long) located $11 \mathrm{~km}$ northeast of Whitman, Nebr. Hay was harvested and baled into $500-\mathrm{kg}$ round bales from 2 rectangular $(100 \times 330 \mathrm{~m})$, subirrigated meadow plots. Soils of the subirrigated meadow are classified as Gannett-Loup fine sandy loam (coarse-loamy, mixed, mesic Typic Haplaquoll). Plots were harvested to represent 2 stages of plant growth: immature hay (1 June 1994), characterized as being vegetative to elongation phase; and mature hay (1 October 1994), characterized as being post-reproductive (Moore and Moser 1995). Dominant species of the subirrigated meadow plots were Kentucky bluegrass (Poa pratensis L.), slender wheatgrass [Elymus trachycaulum (Link) Gould ex Shinn.], quackgrass [Elytergia repens (L.) Nevski], redtop (Agrostis stolonifera L.), timothy (Phleum pratense L.), several species of sedges (Carex spp.), smooth bromegrass (Bromus inermis Leyss.), and reed canarygrass (Phalaris arundinacea L.). Less abundant species were prairie cordgrass (Spartina pectinata Link), rushes (Juncus spp. and Eleocharis spp.), big bluestem (Andropogon gerardii Vitman), indiangrass [Sorgastrum nutans (L.) Nash], switchgrass (Panicum virgatum L.), and several species of clover (Trifolium spp). Mean percentage of total plant basal area for species of an adjacent meadow with similar soils and elevation was $26 \%$ Kentucky bluegrass, $25 \%$ wheatgrass (composite of slender wheatgrass and quackgrass), $14 \%$ sedge, $8 \%$ timothy, $8 \%$ red clover (Trifolium pratense L.), $5 \%$ rushes, $4 \%$ redtop, $3 \%$ smooth bromegrass, and $3 \%$ reed canarygrass. The remaining component was comprised of big bluestem, indiangrass, and other forbs (Nichols 1991, Reece et al. 1994).

Hay was separated into leaf and stem fractions at the USDA-ARS Southern Plains Range Research Station at Woodward, Okla. Bales were unrolled and hay was chopped with a forage chopper into 3- to 5-cm lengths. Chopped hay was separated into leaf and stem fractions using a Clipper Cleaner Model Super $69 \mathrm{D}^{1}$ dual flow air separation system (A.T. Ferrel \& Co., Saginaw, Mich.). The dual air system forces air into the separation chamber from opposing directions (e.g. top and bottom). Chopped hay enters at the center and moves across the opposing air flows. The opposition from the flows results in separation based on weight of the fractions. The heavier steri fraction separates and moves across ihe chamber at a lower angle than the lighter leaf fraction. Fractions are individually recovered. Air flows were continually monitored and adjusted to obtain leaf stem separation. Sub-samples of leaf and stem fractions were collected and manually separated and found to be $90 \%$ of their intended fraction.

Steers were housed under environmentally controlled conditions in metabolism stalls. Fourteen days before trial initiation, steers were allowed ad libitum access to long-stem subirrigated meadow hay that was harvested 1 August from an adjacent meadow of similar species composition. Steers were assigned randomly to 1 of 4 hay fraction diets: immature leaf, immature stem, mature leaf, or mature stem. Steers were fed every 2 hours with automatic feeders which allowed ad libitum ( $10 \%$ daily refusal) access to diets. To avoid associated effects of potential ruminal $\mathrm{N}$ deficiencies on intake, passage rates, and particle breakdown of the fiber component, solubilized urea was supplemented via the rumen cannula. Urea was added at 12-hour intervals to steers fed immature stem $\left(77 \mathrm{~g} \mathrm{day}^{-1}\right)$, mature leaf $\left(91 \mathrm{~g} \mathrm{day}^{-1}\right)$, and mature stem diets $\left(108 \mathrm{~g} \mathrm{day}^{-1}\right)$. Urea was supplemented as a percentage of the total dietary $\mathrm{N}$ and calculated to equal the percentage of total $\mathrm{N}$ in the immature leaf diet. Period lengths were 15 days, with 7 days for diet adaptation and 8 days for collection. Refusals were collected, weighed, and subsampled daily. Subsamples were stored for later analysis. Daily OMI was determined by difference. On day 8 , steers were fitted with fecal collection bags and

\footnotetext{
Trade names and company names are included for the benefit of the reader, and imply no endorsement or preferential treatment of the product by University of Nebraska.
}

total feces were collected until day 13 . Fecal bags were weighed, emptied, and subsampled every 12 hours. Subsamples were frozen for later analysis of dry matter $(\mathrm{DM})$, organic matter $(\mathrm{OM})$, and particle size.

\section{Particulate Passage Estimates}

Particulate passage rates and retention times were det'srmined on 2 different particle sizes. Lirge particles were classified as those thit were retained on a $1.7-\mathrm{mm}$ screen, whereas small particles were classified as those that cleared a $1.7-\mathrm{mm}$ screen but were retained on a $0.212-\mathrm{mm}$ $s$ s.reen. Hay fractions were soaked in water for 24 hours before being separated into large or small particles. Particles were sieved with a FRITSCH electromagnetic siever (Idar-Oberstein, West Germany), the lid of which was equipped with a shower and the pan with a vacuum system. Sieving was done with a vibration amplitude of $6 \mathrm{~mm}$ for $10 \mathrm{~min}$ (Shaver et al. 1988). Screen sizes were: $6.30,4.75,3.35$, 1.70 , and $0.212 \mathrm{~mm}$. Particles on upper screens were combined into a large particle pool while those retained on the 0.212 $\mathrm{mm}$ screen constituted the small particles.

Large particles from the 4 hay fractions were labeled with $\mathrm{Yb}$ acetate and small particles were labeled with Er acetate using modified procedures described by Teeter et al. (1984). Large particles were soaked for 24 hours in a $15 \mathrm{mM}$ aqueous Yb solution. After soaking, excess fluid was poured off and the remaining sample was soaked in $100 \mathrm{mM}$ acetic acid solution for 12 hours with occasional stirring. After soaking in acetic acid, particles were rinsed with slow flowing water overnight into a plastic tub covered with several layers of cheese cloth. Particles were then squeezed dry and soaked again in $100 \mathrm{mM}$ acetic acid solution for 5 to 6 hours with occasional stirring, squeezed dry, spread on trays, and dried in a forced-air oven at $50^{\circ} \mathrm{C}$. Small particles were labeled with $\mathrm{Er}$ following the same procedures using 20 $\mathrm{mM}$ Er aqueous solution.

In each period on day 3 at 2000 hours, steers were pulse-dosed intraruminally with both $\mathrm{Yb}$ and Er labeled particles. The dose was placed in the mid-dorsal region of the rumen (Krysl et al. 1987). Each steer was dosed with $200 \mathrm{~g}$ air-dried Yb labeled large particles and $150 \mathrm{~g}$ airdried Er labeled small particles. At 0800 hour the following 3 days, ruminal evacuations were made (Vanzant et al. 1993). Rumen contents were weighed and mixed thoroughly, sampled for $\mathrm{pH}$ and subsampled for DM and marker determinations. 
Subsamples obtained during ruminal evacuations represented 12,36 , and 60 hours post-marker dosing. Following each rumen evacuation, the omasum orifice was palpated and approximately $30 \mathrm{~g}$ of contents were removed from between the omasal folds (Moir 1984). Omasal contents were combined across days, frozen and stored for subsequent particle size analysis.

\section{Particulate Size and Distribution}

Particle size was determined using wet sieving techniques on subsamples of individual hay fractions, ruminal and omasal contents, and feces. Individual hay fractions were collected and soaked in water for 24 hours, excess water was removed, and samples were stored at $-18^{\circ} \mathrm{C}$ for later particle size determination. Ruminal digesta samples were collected from 4 sites within the reticulorumen on day 8 at 0800 hour, before interval feeding and stored at $-18^{\circ} \mathrm{C}$ for later particle size analysis. Reticulorumen sampling sites were: 1) anterior dorsal sac; 2) caudo-dorsal sac; 3) caudo-ventral sac; and 4) reticulum. At 0800 hour on days 13 to 15 , ruminal evacuations were made and subsamples collected to estimate DM content of the reticulorumen (Vanzant et al. 1993). Samples collected at the anterior dorsal sac or caudo-dorsal sac were a composite of 2 grab samples. Samples collected at the caudo-ventral sac or reticulorumen were obtained by passing a 300-ml cup, capped by placing the hand over the opening, into the sampling sites. Omasal samples were a composite collected during ruminal evacuations. Fecal samples were a composite of subsamples collected during total fecal collections.

Particle size was determined on duplicate samples of the hay fractions, ruminal, omasal, and fecal contents using wet sieving techniques described by Prigge et al. (1990). Particles were separated using a FRITSCH (Idar-Oberstein, West Germany) electromagnetic siever equipped with a lid shower and an evacuation system. Approximately $15 \mathrm{~g}$ of wet sample ( 3 to $4 \mathrm{~g} \mathrm{DM}$ ) were placed on the top screen and sieving was done with a vibration amplitude of $6 \mathrm{~mm}$ for $10 \mathrm{~min}$ (Moseley 1984, Shaver et al. 1988) with screen apertures of $6.30,4.74,3.35,1.70$, $1.18,0.85,0.60$, and $0.212 \mathrm{~mm}$. Particles retained on individual sieves were rinsed onto preweighed $15-\mathrm{cm}$ filter paper and dried $\left(50^{\circ} \mathrm{C}\right)$ in a forced-air oven for 48 hours to determine retained DM. Dry residue retained on individual screens was expressed as a percentage of the total DM sieved (Shaver et al. 1988). The soluble fraction and particles less than the 0.212$\mathrm{mm}$ screen size were calculated by difference. Geometric mean diameter was calculated according to procedures outlined by Waldo et al. (1971). Five particle pools were determined based on the cumulative DM retained on selected sieve screens $(\geq 3.36, \geq 1.18, \geq 0.60,<0.60$, or $<0.212-\mathrm{mm}$ screen).

\section{In Situ Procedures}

Rate and extent of in situ neutral detergent fiber (NDF) disappearance were determined on individual hay fractions during all periods. A 5-g subsample of each hay fraction was ground to pass through a $2-\mathrm{mm}$ screen in a Wiley Mill and was placed into a pre-weighed, labeled Dacron bag $(10 \times 20 \mathrm{~cm}$, avg pore size $=53 \pm 10 \mu \mathrm{m}$; Ankom, Fairport, N.Y.). Individual bags were sealed by wrapping the open end around a \#8 rubber stopper that was secured with a \#18 rubber band. The bag was folded over the rubber band and a second rubber band was added. Sample bags were soaked in water $\left(39^{\circ} \mathrm{C}\right)$ for $20 \mathrm{~min}$ before rumen incubation. Incubation times were: 4, 8, 12, 24, 48, 72, and 96 hours. Duplicate sample bags were incubated in a polyester mesh bag (36 x 42 $\mathrm{cm})$. Bags were placed in the fluid phase of the ruminal ventral sac and incubated in descending order which facilitated removal of all bags at 1 time point. Bags were washed and rinsed according to procedures outlined by Wilkerson et al. (1995).

Neutral detergent fiber of in situ residue was determined using methods described by Van Soest et al. (1991). Approximately $0.5 \mathrm{~g}$ of in situ residue was analyzed for NDF in duplicate for the $0,4,8,12,24$, 48, 72, and 96 hour incubations. Rate and extent of fiber degradation and apparent extent of ruminal digestion were calculated as described by Grant and Mertens (1992) and Grant and Weidner (1992).

\section{Laboratory Analyses}

Diets, refusals, ruminal contents, and fecal samples were dried in a forced-air oven $\left(50^{\circ} \mathrm{C}\right)$ and ground to pass through a $1-\mathrm{mm}$ screen in a Wiley Mill. Samples were analyzed for DM (AOAC 1984), NDF (Van Soest et al. 1991), acid detergent fiber (ADF, Van Soest 1963), and crude protein (AOAC 1984). In vivo OMD was calculated following procedures outlined by Schneider and Flatt (1975).

Rumen subsamples with labeled $\mathrm{Yb}$ or Er fractions were prepared for analysis
(Karimi et al. 1986) by adding $14.9 \mathrm{ml}$ of $0.01 \mathrm{M}$ Diethylenetriaminepentaacetic acid (DTPA) to $0.2 \mathrm{~g}$ of sample. Samples were shaken for $35 \mathrm{~min}$, then filtered (Whatman \#4 filter paper, Whatman, Maidstone, UK) into vials and analyzed by atomic absorption spectroscopy with a nitrous oxide/acetylene flame (McCollum and Galyean 1985). Passage of particles was assumed to follow first order kinetics. Rumen $\mathrm{Yb}$ and Er disappearance curves were used to calculate the rate of particle passage $\left(k_{p}\right)$ out of the rumen. Fractional passage rate represented the natural logarithmic slope of the descending portion of the disappearance curve. Retention time was calculated as the reciprocal of the natural logarithmic slope.

Undegraded intake protein (UIP) of the individual hay fractions was determined by combining large particle passage rate $\left(\mathrm{k}_{\mathrm{p}}\right)$ and rate of in situ $\mathrm{N}$ degradation $\left(\mathrm{k}_{\mathrm{d}}\right)$. Undegraded intake protein values were determined using a dacron bag procedure with incubation times of $4,8,12$, and 24 hours (Wilkerson et al. 1995) and by using the following equation: [ $b$ fraction $\mathrm{x}$ $\left(\left(\mathrm{k}_{\mathrm{p}} /\left(\mathrm{k}_{\mathrm{p}}+\mathrm{k}_{\mathrm{d}}\right)\right)\right]$. The $\mathrm{b}$ fraction represented the $\mathrm{N}$ pool that has the potential for escape. Undegraded intake protein values were corrected for microbial attachment using purine analysis as described by Zinn and Owens (1986) and Aharoni and Tagari (1991).

Undegraded intake protein values were also determined based on protein solubility classifications as described by Van Soest (1994). The $b$ fraction and $k_{d}$ were determined using in situ residues at 4,8 , 12 , and 24 hours. Neutral detergent-insoluble protein was selected as the protein fraction that best represented the $b$ fraction. This protein fraction was classified as being insoluble in neutral detergent but soluble in acid detergent and having a slow rate of enzymatic degradation.

Neutral detergent-insoluble protein was determined on the initial hay fractions and on in situ residue from bags incubated in the rumen for $4,8,12$, and 24 hours. About $1 \mathrm{~g}$ of residue was allowed to reflux for 1 hour in NDF solution (Van Soest et al. 1991). After refluxing, the NDF residue and solution were filtered (Whatman \#541 filter paper, Whatman, Maidstone, UK) and rinsed 3 times with boiling water to remove NDF solution. Percentage neutral detergent insoluble protein was calculated by determining the crude protein concentration of the filtered NDF residue (AOAC 1984) divided by the sample weight. A blank filter paper treated with hot NDF solution and rinsed 3 times with boiling 
water was used to correct for any $\mathrm{N}$ contamination originating from the filter paper or NDF solution. Rate $\left(\mathrm{k}_{\mathrm{d}}\right)$ was determined by taking the natural logarithm of the percentage NDF multiplied by the percentage neutral detergent-insoluble protein at each time point. Rate represented the natural logarithmic slope of the descending portion of the disappearance curve.

\section{Statistical Analysis}

Organic matter intake, (OMI), organic matter digestibility (OMD), rumen dry matter (DM) fill, rumen volume, particulate passage of large and small particles, $\mathrm{pH}$ (single time point), undergraded intake protein (UIP), and rate and extent of NDF disappearance were analyzed as a $4 \times 4$ Latin square. Factors included in the model were steer, period, maturity, and individual leaf or stem fraction. Steer was considered a random effect. Treatments were compared using predetermined contrasts. Due to the expense of fraction separation and an under-estimation of actual fraction intake at the time of separation, there were only enough mature stems for 2 complete collection periods compared to 4 periods for immature leaves, immature stems, and mature leaves. Results for mature stems were analyzed using 2 periods (Cochran and Cox 1992). Data were analyzed using Mixed Model Procedures of SAS (1992). All differences mentioned are significant at the $\mathrm{P}<0.05$ probability level unless otherwise noted.

\section{Results}

\section{Diet Composition}

The separation technique on a dry weight basis provided purity values greater than $90 \%$. The stem fraction for both immature and mature hays contained stems plus some leaf sheaths and seed heads, while the leaf fractions contained leaf blades plus leaf sheaths, and some lighter seed heads.

Crude protein $(\mathrm{CP})$ of immature hay fractions was greater than mature hay fractions. Immature leaves contained $26 \%$ more CP than immature stems and mature leaves contained $27 \%$ more $\mathrm{CP}$ than mature stems (Table 1). Neutral detergent fiber of immature and mature hay fractions were similar. Leaf and stem fractions within stage of maturity did not differ in NDF. Mature hay fractions had higher ADF than immature hay fractions. Immature leaves and stems did not differ in ADF content. However, mature leaves had higher ADF concentrations than mature stems. Why ADF content of immature leaves and stems did not differ while mature leaves had a greater ADF concentration than mature stems is not apparent. A partial explanation for the lack of difference in ADF content between the immature hay fractions could be related to the concentration of leaf sheaths in the leaf fraction.

\section{Intake, DM Fill, Digestibility and Passage}

Organic matter intake (OMI) of steers fed immature hay fractions was greater than that of steers fed mature fractions (Table 2). Organic matter intake of leaves and stems within stage of maturity did not differ. Organic matter digestibility (OMD) was lower for steers fed mature hay fractions when compared with steers fed immature hay fractions (Table 2). Immature leaf and stem fractions did not differ in OMD. Likewise, OMD of mature leaves and stems was similar.

Particulate passage rates of large and small particles were faster for immature hay fractions than mature fractions (Table 2). Passage rate of immature leaves, regardless of particle size, was faster than rates for immature stems. Large particle passage rate was faster for mature leaves than for mature stems. However, passage rate of small particles for mature stems and leaves did not differ.

Dry matter (DM) fill and total rumen volume were not affected by stage of maturity and leaf and stem fractions within stage of maturity did not differ. Ruminal $\mathrm{pH}$ was similar for immature and mature hay fractions, and leaf and stem fractions within stage of maturity did not differ.

Table 1. Chemical composition of subirrigated meadow immature and mature leaf and stem fractions fed to beef steers.

\begin{tabular}{lrrrrrcc}
\hline \hline \multirow{2}{*}{ Item $^{2}$} & \multicolumn{2}{c}{ Immature } & \multicolumn{2}{c}{ Mature } & \multicolumn{3}{c}{ Contrasts $^{1}$} \\
\cline { 2 - 8 } Organic matter (\% of DM) & Leaf & Stem & Leaf & Stem & $(1)$ & $(2)$ & $(3)$ \\
Ash (\% of DM) & 12.4 & 91.3 & 85.0 & 90.5 & NS $^{3}$ & NS & NS \\
Crude protein (\% of OM) & 12.9 & 8.7 & 15.0 & 9.5 & $*$ & $*$ & $*$ \\
NDIN (\% of DM) & 3.4 & 2.6 & 9.2 & 6.7 & $*$ & $*$ & $*$ \\
BEP $(\%$ of DM) & 2.1 & 2.0 & 2.4 & 1.9 & $*$ & NS & $*$ \\
NDF $(\%$ of OM) & 78.4 & 74.0 & 77.9 & 75.4 & NS & NS & NS \\
ADF (\% of OM) & 46.6 & 44.7 & 53.0 & 45.7 & NS & $*$ & $*$ \\
ADIN (\% of N) & 15.6 & 16.0 & 20.9 & 22.0 & NS & NS & $*$ \\
\hline
\end{tabular}

Contrasts 1 = immature leaves vs immature stems; 2 = mature leaves vs mature stems; 3 = immature hay fractions vs mature hay fractions.

${ }^{2} \mathrm{NDIN}=$ Escape protein calculated using neutral detergent insoluble $\mathrm{N}(\%$ of DM $) ; \mathrm{BEP}=$ Escape protein calculated from in situ data corrected for microbial attachment; NDF = neutral detergent fiber; ADF = acid detergent fiber; ADIN = acid detergent insoluble nitrogen.

${ }^{3} \mathrm{NS}$ contrast not significant $\mathrm{P}>0.05$.

*Contrast significant $\mathrm{P}<0.05$.

\section{Particle Size Distribution}

Geometric mean diameter of mature hay fractions was $42 \%$ larger than for immature fractions. Geometric mean diameter of mature leaves was $20 \%$ greater than mature stems (Table 3). About $89 \%$ of the total DM sieved for mature leaf and stem fractions was retained within the $\geq 1.18$ $\mathrm{mm}$ pool. More DM was retained $(4.5 \%)$ within the $\geq 1.18$-mm pool for immature stems than for immature leaves).

Geometric mean diameter of particles or particle pools at the 4 rumen sites was not different. No 2-way interaction existed for maturity $\mathrm{x}$ site or fraction $\mathrm{x}$ site. Given that the 4 sites were not different, sites within maturity level and fraction were pooled (Table 3 ). The geometric mean diameter of rumen particles for mature stems was $38 \%$ larger than mature leaves. Immature stems had a geometric mean diameter $25 \%$ larger than immature leaves. No differences between immature leaves and stems were observed for coarse particles ( $\geq 3.36-\mathrm{mm}$ ) with approximately $18.1 \%$ of the total ruminal DM sieved retained in this pool. Retained ruminal DM for the coarse $(\geq 3.36-\mathrm{mm})$ particle pool was similar for mature stems and leaves and approximately $13.5 \%$ of the total sieved DM was retained (Table 3 ). The fine particle pool $(<0.60-\mathrm{mm})$ comprised a large portion of the total retained DM. Immature leaves had approximately leaves had approximately $24 \%$ more DM retained within the fine particle pool than mature stems (Table 3).

Estimates of geometric mean diameter for both omasal and fecal contents were similar. Stage of maturity did not affect geometric mean diameter or particle distri- 
Table 2. Organic matter intake, digestibility, rumen DM fill, and passage rates in steers fed subirrigated meadow immature and mature leaf and stem hay fractions.

\begin{tabular}{|c|c|c|c|c|c|c|c|c|c|c|}
\hline \multirow[b]{2}{*}{ Item $^{2}$} & \multicolumn{2}{|c|}{ Immature } & \multicolumn{2}{|c|}{ Mature } & \multicolumn{6}{|c|}{ Contrasts $^{1}$} \\
\hline & Leaf & Stem & Leaf & Stem & (1) & $\mathrm{SE}$ & (2) & $\mathrm{SE}$ & (3) & $\mathrm{SE}$ \\
\hline OMI, kg & 7.0 & 7.0 & 5.5 & 5.7 & $\mathrm{NS}^{3}$ & 0.2 & NS & 0.3 & $*$ & 0.2 \\
\hline OMI, g/kg BW & 15.4 & 15.4 & 12.1 & 12.8 & NS & 0.4 & NS & 0.5 & $*$ & 0.3 \\
\hline OMD, $\%$ & 62.9 & 63.5 & 54.5 & 56.9 & NS & 1.9 & NS & 2.4 & $*$ & 1.5 \\
\hline RDMF, g/kg BW & 17.6 & 19.3 & 18.3 & 21.5 & NS & 1.3 & NS & 1.8 & NS & 1.3 \\
\hline $\mathrm{RV}, \mathrm{g} / \mathrm{kg} \mathrm{BW}$ & 138.3 & 149.1 & 143.3 & 151.5 & NS & 7.4 & NS & 9.9 & NS & 6.3 \\
\hline $\mathrm{pH}$ & 6.6 & 6.6 & 6.8 & 6.8 & NS & 0.2 & NS & 0.2 & NS & 0.1 \\
\hline $\mathrm{LPP}, \% / \mathrm{h}$ & 3.8 & 2.5 & 2.5 & 2.1 & $*$ & 0.1 & $*$ & 0.1 & $*$ & 0.1 \\
\hline LPR, time, $\mathrm{h}$ & 26.3 & 40.0 & 40.0 & 47.6 & $*$ & 0.8 & $*$ & 1.1 & $*$ & 0.7 \\
\hline $\mathrm{SPP}, \% / \mathrm{h}$ & 5.1 & 3.5 & 3.0 & 2.8 & $*$ & 0.1 & NS & 0.1 & $*$ & 0.1 \\
\hline SPR time, $h$ & 19.6 & 28.6 & 33.3 & 35.7 & $*$ & 1.2 & NS & 1.7 & $*$ & 1.1 \\
\hline NDFD, $\% / \mathrm{h}$ & 5.3 & 3.8 & 3.9 & 3.7 & $*$ & 0.0 & NS & 0.0 & NS & 0.0 \\
\hline ENDF, $\mathrm{h}$ & 79.1 & 70.8 & 67.5 & 55.7 & $*$ & 1.5 & $*$ & 2.0 & $*$ & 1.3 \\
\hline AEDL & 43.8 & 41.3 & 37.7 & 35.7 & NS & 1.7 & NS & 2.3 & $*$ & 1.5 \\
\hline AEDS & 37.8 & 35.0 & 35.3 & 31.8 & NS & 1.8 & NS & 2.4 & NS & 1.5 \\
\hline
\end{tabular}

${ }_{2}$ Contrasts $1=$ immature leaves vs immature stems; $2=$ mature leaves vs mature stems; $3=$ immature hay fractions vs mature hay fractions.

${ }^{2} \mathrm{OMI}=$ organic matter intake; $\mathrm{OMD}=$ organic matter digestibility; $\mathrm{RDMF}=$ rumen dry matter fill; $\mathrm{RV}=$ rumen volume; $\mathrm{LPP}=$ passage rate of $\mathrm{Yb}$-labeled large particles $>1.7$ mm screen; $L P R=$ mean retention time of Yb-labeled large particles; SPP = passage rate of Er-labeled small particles $<1.7 \mathrm{~mm}$ and $>.212 \mathrm{~mm}$ screen; SPR $=$ mean retention time of Erlabeled particles; NDFD = in situ neutral detergent fiber disappearance; ENDF $=$ in situ neutral detergent fiber extent of disappearance; AEDL $=$ apparent extent of digestion of Yblabeled large particles; AEDS = apparent extent of digestion of Er-labeled small particles.

${ }^{3} \mathrm{NS}$ contrast not significant $\mathrm{P}>0.05$.

${ }^{*}$ Contrast significant $\mathrm{P}<0.05$.

bution (Table 3). A large portion of retained fecal and omasal DM sieved was retained within the fine particle pool $(<0.60-\mathrm{mm})$. More immature leaf DM was retained compared with immature stem. Similarly, more mature leaf DM was retained within the fine particle pool than mature stems (Table 3 ).

\section{In Situ Disappearance}

Rate of NDF disappearance was faster for immature leaves than immature stems. Mature leaves and stems had similar rates of NDF disappearance. Extent of NDF disappearance was affected by maturity and immature fractions required longer rumen incubation times to reach extent of NDF disappearance than mature hay fractions (Table 2). Immature stems reached extent of NDF disappearance more quickly than immature leaves and mature stems also required longer rumen incubation to reach extent of NDF disappearance than mature leaves (Table 2).

Apparent extent of ruminal digestion was similar for small particles regardless of maturity level or fraction type. Apparent extent of digestion of large particles was greater for immature hay fractions than mature fractions. Apparent extent of ruminal digestion of leaf and stem large particles within maturity were similar (Table 2).

\section{Discussion}

Organic matter intake (OMI) of the leaf or stem hay fractions within stage of maturity was similar. Previous work (Poppi et al. 1980, Laredo and Minson 1975, and Cherney et al. 1990) found marked differences in voluntary intake of leaves or stems within stage of maturity by steers and sheep when diets were supplemented with rumen degradable $\mathrm{N}$. They attributed the reduction in voluntary intake of stems to differences in retention time, apparent digestion, and passage rates between the 2 fractions. In contrast, differences observed for passage rate and ruminal retention time between leaf and stem fractions within maturity were not associated with differences in OMI in this study. The similarity in OMI between leaves and stems is best explained by similarities in fraction quality. Immature leaves and stems and mature leaves and stems contained similar NDF levels. Acid detergent fiber concentrations were similar for immature leaves and stems; however, mature leaves contained more ADF than mature stems. Dry matter (DM) fill of steers fed either immature stems or immature leaves was similar which indicated that rumen kinetics were similar for leaves and stems. Differences in DM fill and voluntary intake observed in previous work might be related to the resistance of forage fractions to mechanical and microbial breakdown. Generally as forages mature, secondary cell wall devel- opment increases. This, coupled with lignification, makes mechanical and microbial breakdown more difficult (Van Soest 1994). Differences between leaf and stem cell structures and epidermal attachment can make stems more resistant to both microbial and mechanical breakdown (Minson and Wilson 1994). Previous work has demonstrated that the slower passage of stem material from the rumen apparently reduced voluntary intake and as forage matured, passage rates were reduced for both leaves and stems. In the current study, passage rates and rates of ruminal NDF disappearance of mature hay fractions were slower than immature hay fractions, thus resulting in a reduction in OMI and organic matter digestibility (OMD).

Similarity of leaf and stem fraction OMD within respective stage of maturity can be attributed to slower passage and longer ruminal retention time of the stem fraction when compared with the leaf fraction. These findings are similar to those reported by Poppi et al. (1985) and Hendricksen et al. (1981). Haferkamp et al. (1995) observed that the leaf fraction of RS-2 (quackgrass $x$ bluebunch wheatgrass [Pseudoroegneria spicata (Pursh.) Love]) hybrid had consistently higher in vitro OM digestibility than stem throughout the growing season. Ruminal retention time is important to digestion and particle size reduction. In vitro data do not reflect differences in retention times and resistance to mechanical breakdown. Therefore, differences in in vitro OM digestibility are 
not surprising because in vitro digestion does not account for passage rate and retention time, whereas in vivo procedures do. Differences in the 2 methods would likely occur if passage rate and retention were different. The longer forage is retained within the rumen the greater the opportunity for digestion and particle breakdown. Stems were retained longer, thus they had a greater opportunity for digestion.

For particles to exit the rumen via passage, Poppi et al. (1985) reported that particles must be reduced to a size small enough to pass through a $1.18-\mathrm{mm}$ screen. Changes in the chemical composition of forage due to maturation can alter the relative resistance of a forage particle to digestibility and particle size reduction.

Bailey et al. (1990) reported that particle size of ruminal contents had a direct effect on the rate at which diets are passed from the rumen. They suggested that ruminal particle size was a function of the initial particle size of masticated feed and the rate of particle size reduction due to rumination and microbial breakdown. The geometric mean diameter of pre-ingested hay fractions in this study was larger for leaves than stems, and larger for immature fractions than mature fractions. Following ingestion of the hay fractions, geometric mean diameter of ruminal digesta was larger for stems than leaves which suggested that leaves were less resistant to particle breakdown than are stems.

Poppi et al. (1981) observed that cattle and sheep consumed more leaf than stem, apparently due to shorter retention of the leaf fraction within the rumen. They concluded that the controlling factor of particle retention and hence voluntary intake, was retention time of the small particle pool (particles $\leq 1.18 \mathrm{~mm}$ ). They observed that the small particle pool contained about $72 \%$ of the total ruminal dry matter (DM). In this study, the small particle pool of the hay fractions accounted for 48 to $60 \%$ of the total rumen DM. If small particle retention was the rate limiting factor for organic matter intake (OMI), then the longer retention time of small particles for mature fractions compared with immature fractions could have depressed OMI of the mature fractions. However, if the small particle pool was the rate limiting factor, there should have been OMI differences between immature stem and leaf fractions. In contrast, Prigge et al. (1990) did not find a relationship between digesta passage and ruminal particle size, and concluded that other factors regulate passage from the rumen besides just particle size. Lechner-Doll et al. (1991) observed that

Table 3. Particle size of leaves and stems, ruminal digesta, omasal, and fecal content of subirrigated meadow immature and mature leaf and stem hay fractions fed to beef steers.

\begin{tabular}{lcrrrrrr}
\hline \hline & \multicolumn{2}{c}{ Immature } & \multicolumn{2}{c}{ Mature } & \multicolumn{3}{c}{ Contrasts $^{1}$} \\
\cline { 2 - 8 } Site $^{2}$ & Leaf & Stem & Leaf & Stem & $(1)$ & $(2)$ & $(3)$ \\
\hline Diet & & & & & & & \\
$\quad$ Screen size, mm & & & & & & & $*$ \\
$\quad \geq 3.36$ & 57.5 & 48.7 & 76.8 & 70.2 & $*$ & $*$ & $*$ \\
$\quad \geq 1.18$ & 74.5 & 82.6 & 89.6 & 87.5 & $*$ & $\mathrm{NS}^{2}$ & $*$ \\
$\quad \geq 0.60$ & 86.9 & 91.3 & 93.2 & 90.7 & $*$ & NS & $*$ \\
$\quad<0.60$ & 13.1 & 8.7 & 6.8 & 9.2 & $*$ & NS & $*$ \\
$\quad<0.212$ & 8.3 & 6.0 & 6.0 & 8.8 & $*$ & $*$ & NS \\
GMD $^{3}$, mm & 3.1 & 2.9 & 5.7 & 4.5 & NS & $*$ & $*$ \\
Rumen & & & & & & & \\
Screen size, mm & & & & & & & \\
$\quad \geq 3.36$ & 15.3 & 20.8 & 9.7 & 17.3 & NS & NS & NS \\
$\quad \geq 1.18$ & 33.0 & 41.5 & 27.7 & 39.8 & $*$ & $*$ & NS \\
$\quad \geq 0.60$ & 42.0 & 51.7 & 38.6 & 53.0 & $*$ & $*$ & NS \\
$\quad<0.60$ & 58.0 & 48.3 & 61.4 & 47.0 & $*$ & $*$ & NS \\
$\quad<0.212$ & 33.8 & 27.0 & 35.3 & 23.3 & NS & $*$ & NS \\
GMD, mm & 0.6 & 0.8 & 0.5 & 0.8 & $*$ & $*$ & NS
\end{tabular}

Omasum

Screen size, $\mathrm{mm}$

$\geq 3.36$

$\geq 1.18$

$\geq 0.60$

$<0.60$

$<0.212$

GMD, mm

0.9
8.3
13.9
86.1
55.3
0.2

1.1
6.9
14.4
85.6
45.6
0.3
0.3
6.7
12.7
87.3
56.1
0.2

1.4
7.2
15.3
84.7
43.0
0.3

$\begin{array}{lll}\text { NS } & * & \text { NS } \\ \text { NS } & \text { NS } & \text { NS } \\ \text { NS } & \text { NS } & \text { NS } \\ \text { NS } & \text { NS } & \text { NS } \\ \text { NS } & \text { NS } & \text { NS } \\ \text { NS } & \text { NS } & \text { NS }\end{array}$

Feces

\begin{tabular}{lrrrrlll} 
Screen size, mm & & & & & & & \\
$\geq 3.36$ & 0.5 & 0.7 & 0.6 & 0.7 & NS & NS & NS \\
$\geq 1.18$ & 3.4 & 5.6 & 4.2 & 5.3 & $*$ & NS & NS \\
$\geq 0.60$ & 7.9 & 13.4 & 8.4 & 14.0 & $*$ & $*$ & NS \\
$<0.60$ & 92.1 & 86.6 & 91.7 & 86.0 & $*$ & $*$ & NS \\
$<0.212$ & 69.4 & 52.9 & 62.7 & 47.4 & $*$ & NS & NS \\
GMD, mm & 0.2 & 0.2 & 0.2 & 0.2 & NS & NS & NS \\
\hline
\end{tabular}

${ }^{\mathrm{T}}$ Contrasts 1 = immature leaves vs immature stems; 2 = mature leaves vs mature stem; $3=$ immature hay fractions vs mature hay fractions.

${ }_{3}^{2}$ NS Contrast not significant $(\mathrm{P}>0.05)$.

${ }^{3} \mathrm{GMD}=$ geometric mean diameter (Waldo et al. 1971)

*Contrast significant $(\mathrm{P}<0.05)$.

the breakdown of large particles is faster than passage of small particles, suggesting that small particles are selectively retained in the rumen. They concluded that particle density and size are the primary determinants of passage. Minson and Wilson (1994) suggested that as plants mature vascular cells and sclerenchyma strands thicken and lignify in both stems and leaves, making these particles stronger and more resistant to size reduction.

Poppi et al. (1980) reported that fecal particle size can provide an indication of the critical size for digesta to pass from the rumen. Poppi et al. (1981) observed that the critical size for ruminal passage was $1.18 \mathrm{~mm}$ for both cattle and sheep. Similarly, no differences were observed between the critical passage size of leaves and stems. Shaver et al. (1988) suggested that the critical particle size for rumen escape in dairy cattle was greater than $1.18 \mathrm{~mm}$ since 20 to $36 \%$ of fecal DM was retained on screens $\geq 1.18 \mathrm{~mm}$ compared with the 1 to $2 \%$ retention reported by Poppi et al. (1981). Findings of this study are in agreement with those observed by Poppi et al. (1981) in that the critical particle size for rumen escape for both leaves and stems was $\leq 1.18 \mathrm{~mm}$.

Although differences were observed in particle passage rates, retention times, resistance to particle breakdown, and digestion rates of leaf and stem fractions, these differences had no effect on OMI. Previous studies have demonstrated marked differences in voluntary intake of leaves and stems. Previous studies differ from this study in that leaf and stem differences were evaluated using a single monoculture forage species (i.e. ryegrass Lolium perenne L., crabgrass Digitaria decumbens Stent., windmill grass Chloris gayana Kunth, sorghum Sorghum bicolor (L.) Moench., pearl millet Pennisetum glaucum L., barley Hordeum vulgar L., or oats Avena sativa L.). Hay fractions evaluated in the present study were harvested 
from a complex population consisting of $69 \%$ cool-season grasses, $23 \%$ sedges and rushes, and $8 \%$ forbs. Temperature, competition for water and nutrients, shading, and other environmental factors can cause deviations in forage quality, even when harvested at the same maturity (Buxton and Fales 1994). Hay was harvested in this study under conditions such that the quality of leaf and stem fractions within stage of maturity were similar, thus no differences in OMI or organic matter digestibility (OMD) occurred. Differences in quality between immature and mature forages resulted in lower OMI and OMD in steers fed mature leaf or stem hay fractions compared with steers fed immature fractions.

\section{Conclusions}

As forage grasses mature, particulate passage rates decrease, ruminal retention times increase, and forage particles become more resistant to mechanical and microbial breakdown. We conclude that these changes reduced voluntary intake of steers fed mature leaf and stem fractions compared with steers fed immature fractions, even when diets were similar in rumen degradable $\mathrm{N}$. The reduction in OMI was a function of the physical and chemical properties of the hay fractions. Quality of immature leaves and stems was similar, thus resulting in similar OMI and OMD of steers fed these fractions. Likewise, quality of mature leaves and stems was similar, which resulted in similar OMI and OMD of steers fed those fractions. In this study, time of harvest had a greater impact on animal OMI than did the individual leaf or stem fractions when rumen degradable $\mathrm{N}$ was similar.

\section{Literature Cited}

Aharoni, Y. and H. Tagari. 1991. Use of nitrogen-15 determinations of purine nitrogen fraction of digesta to define nitrogen metabolism traits in the rumen. J. Dairy Sci. 74:2540-2547.

AOAC. 1984. Official methods of analysis. (14 ${ }^{\text {th }}$ Ed.). Assoc. Official Anal. Chemists, Arlington, Virg.

Bailey, A.T., R.A. Erdman, L.W. Smith, and B. K. Sharma. 1990. Particle size reduction during initial mastication of forages by dairy cattle. J. Anim. Sci. 68:2084-2094.

Buxton, D.R. and S.L. Fales. 1994. Plant environment and quality, p. 155-199. In: G.C. Fahey, Jr., M. Collins, D.R. Mertens, and L.E. Moser (eds.), Forage quality, evaluation, and utilization. Amer. Soc. Agron., Crop Sci. Soc. Amer., Soil Sci. Soc. Amer., Madison, Wis.
Cherney, D.J.R., D.R. Mertens, and J.E. Moore. 1990. Intake and digestibility by wethers as influenced by forage morphology at three levels of forage offering. J. Anim. Sci. 68:4387-4399.

Cochran, W.G. and G.M. Cox. 1992. Experimental Design. John Wiley \& Sons, Inc., New York, N.Y.

Ehle, F.R. 1984. Measurement of mean particle size of forages by wet and dry sieving techniques, p.18-21. In: P.M. Kennedy (ed.), Techniques in particle size analysis of feed and digesta in ruminants. Can. Soc. Anim. Sci., Occasional Pub. 1. Edmonton, Alberta, Can.

Grant, R.J. and D.R. Mertens. 1992. Impact of in vitro fermentation techniques upon kinetics of fiber digestion. J. Dairy Sci. 75:1263-1272.

Grant, R.J. and S.J. Weidner. 1992. Digestion kinetics of fiber: Influence of in vitro buffer $\mathrm{pH}$ varied within observed physiological range. J. Dairy Sci. 75:1060-1068.

Haferkamp, M.R., D.C. Adams, M.M. Borman, E.E. Grings, and P.O. Currie. 1995. Yield and quality of RS-2, a quackgrass $\mathrm{x}$ bluebunch wheatgrass hybrid. J. Range Manage. 48:362-369.

Hendricksen, R.E., D.P. Poppi, and D.J. Minson. 1981. The voluntary intake, digestibility and retention time by cattle and sheep of stem and leaf fractions of a tropical legume (Lablab purureus). Australian J. Agr. Res. 32:389-398.

Karimi, A.R., F.N. Owens, and G.W. Horn. 1986. Simultaneous extractions of $\mathrm{Yb}, \mathrm{Dy}$, and Co from feces with EDTA, DCTA, or DTPA. J. Anim. Sci. 63(Suppl. 1):447.

Krysı, L.J., M.J. Galyean, M.B. Judkins, M.E. Branine, and R.E. Estell. 1987. Digestive physiology of steers grazing fertilized and non-fertilized blue grama rangeland. J. Range Manage. 40:493-501.

Laredo, M.A. and D.J. Minson. 1975. The voluntary intake and digestibility by sheep of leaf and stem fractions of Lolium perenne. J. Brit. Grassl. Soc. 30:73-77.

Lechner-Doll, M., M. Kaske, and W.V. Engelhardt. 1991. Factors affecting the mean retention time of particles in the forestomach of ruminants and camelids, $\mathrm{p}$. 455-482. In: T. Tusuda, Y. Sasaki, and R. Kawashima (eds.), Physiological aspects of digestion and metabolism in ruminants. Academic Press, Inc. San Diego, Calif.

McCollum, F.T. and M.L. Galyean. 1985. Influence of cottonseed meal supplementation on voluntary intake, rumen fermentation and rate of passage of prairie hay in beef steers. J. Anim. Sci. 60:570-577.

Minson, D.J. and J.R. Wilson. 1994. Prediction of intake as an element of forage quality, p. 533-563. In: G.C. Fahey, Jr., M. Collins, D.R. Mertens, and L.E. Moser (eds.), Forage quality, evaluation, and utilization. Amer. Soc. Agron., Crop Sci. Soc. Amer., Soil Sci. Soc. Amer., Madison, Wis.

Moir, R.J. 1984. Why an omasum? p. 85-92. In: Ruminant physiology-concepts and consequences. Proc., Symp. Univ. Western Australia. Australia.
Moore, K.J. and L.E. Moser. 1995. Quantifying developmental morphology of perennial grasses. Crop Sci. 35:37-43.

Moseley, G. 1984. The analysis and description of particle size distribution of digesta, $p$. 22-38. In: P.M. Kennedy (ed.), Techniques in particle size analysis of feed and digesta in ruminants. Can. Soc. Anim. Sci., Occasional Pub. 1. Edmonton, Alberta, Can.

Nelson, C.J. and L.E. Moser. 1994. Plant factors affecting forage quality, p.115-154. In: G.C. Fahey, Jr., M. Collins, D.R. Mertens, and L.E. Moser (eds.), Forage quality, evaluation, and utilization. Amer. Soc. Agron., Crop Sci. Soc. Amer., Soil Sci. Soc. Amer., Madison, Wis.

Nichols, J.T. 1989. Forage production and management practices to meet protein needs on the farm or ranch. p. 114-124. Proc., Range Beef Cow Symp. XI Rapid City, S.Dak.

Nichols, J.T. 1991. Management practices for subirrigated meadows in Nebraska. p. 27-38. Proc., Third Intermountain Meadow Symp. Steamboat Springs, Colo.

Poppi, D.P., R.E. Hendricksen, and D.J. Minson. 1985. The relative resistance to escape of leaf and stem particles from the rumen of cattle and sheep. J. Agr. Sci.(Camb.)105:9-14.

Poppi, D.P., D.J. Minson, and J.H. Ternouth. 1980. Studies of cattle and sheep eating leaf and stem fractions of grasses. In: The voluntary intake, digestibility and retention time in the reticulo-rumen. Australian J. Agr. Res. 32:99-108.

Poppi, D.P., D.J. Minson, and J.H. Ternouth. 1981. Studies of cattle and sheep eating leaf and stem fractions of grasses. III. The retention time in the rumen of large feed particles. Australian J. Agr. Res. 32:123-137.

Prigge, E.C., B.A. Stuthers, and N.A. Jacquemet. 1990. Influence of forage diets on ruminal particle size, passage of digesta, feed intake and digestibility. J. Anim. Sci. 68:4352-4360

Reece, P.E., J.T. Nichols, J.E. Brummer, R.K. Engel, and K.M. Eskridge. 1994. Harvest date and fertilizer effects on native and interseeded wetland meadows. J. Range Manage. 47:178-183.

SAS Institute. 1992. SAS/STAT software, Release 6.07. Cary, N.C.

Schneider, B.H. and W.P. Flatt. 1975. The evaluation of feeds through digestibility experiments. Univ. Georgia Press, Athens, Ga.

Shaver, R.D., A.J. Nytes, L.D. Satter, and N.A. Jorgensen. 1988. Influence of feed intake, forage physical form, and forage fiber content on particle size of masticated forage, ruminal digesta, and feces of dairy cows. J. Dairy Sci. 71:1566-1572.

Streeter, C.L., D.C. Clanton, and O.E. Hoehne. 1968. Influence of advance in season on nutritive value of forage consumed by cattle grazing western Nebraska native range. Univ. Neb. Coll. Agr. and Home Econ., Res. Bull. 227. Lincoln, Neb. 
Teeter, R.G., F.N. Owens, and T.L. Mader. 1984. Ytterbium chloride as a marker for particulate matter in the rumen. J. Anim. Sci. 58:465-473.

Ulyatt, M.J., D.W. Dellow, A. John, C.S.W. Reid, and G.C. Waghorn. 1986. Contribution of chewing during eating and rumination to the clearance of digesta from the ruminoreticulum, p. 500-503. In: L.P. Milligan, W.L. Grovum, A. Dobson (eds.), Control of digestion and metabolism in ruminants. Reston Books, Englewood Cliffs, N.J.

Van Soest, P.J. 1963. Use of detergents in the analysis of fibrous feeds. II. A rapid method for the determination of fiber and lignin. J. AOAC. 46:829-835.
Van Soest, P.J. 1994. Nutritional ecology of the ruminant $\left(2^{\text {nd }}\right.$ ed.). Cornell Univ. Press, Ithaca, N.Y.

Van Soest, P.J., J.B. Robertson, and B.A. Lewis. 1991. Methods for dietary fiber, neutral detergent fiber, and nonstarch polysaccharides in relation to animal nutrition. J. Dairy Sci. 74:3583-3597.

Vanzant, E.S., R.C. Cochran, T.A. Stanley, D.L. Harmon, and E.C. Titgemeyer. 1993. Comparison of ruminal evacuation and marker techniques for estimating rate of passage in beef steers fed alfalfa. J. Anim. Sci. (Suppl.1) 71:268.
Waldo, D. R., L.W. Smith, E.L. Cox, B.T. Weinland, and H.L. Lucas, Jr. 1971. Logarithmic normal distribution for description of sieved forage material. J. Dairy Sci. 54:1465-1469.

Wilkerson, V.A., T.J. Klopfenstein, and W.W. Stroup. 1995. A collaborative study of in situ forage protein degradation. J. Anim. Sci. 73:583-588.

Zinn, R.A. and F.N. Owens. 1986. A rapid procedure for purine measurement and its use for estimating net ruminal protein synthesis. Can. J. Anim. Sci. 66:157-166.

\footnotetext{
Statement of Ownership, Management, and Circulation

(Act. of August 12, 1970, Sec. 3685, Title 39, United States Code)

1. Title of Publication: Journal of Range Management

2. Date of Filing: September 13, 2001

3. Frequency of Issue: Bimonthly

4. Location of Office of Publication: 445 Union Blvd., Ste 230, Lakewood, Colo. 80228

5. Location of General Business Office: Same

6. Name and Address of:

Publisher: Society for Range Management, 445 Union Blvd., Ste 230, Lakewood, Colo. 80228

Editor: Gary Frasier, 7820 Stag Hollow Rd, Loveland, Colo. 80538

Managing Editor: Samuel W. Albrecht, 445 Union Blvd., Ste 230, Lakewood, Colo. 80228

7. Owner: Society for Range Management, 445 Union Blvd., Ste 230, Lakewood, Colo. 80228

8. Known Bondholders, Mortgages, etc.: Membership

9. For Completion by Nonprofit Organizations Authorized to Mail at Special Rates: The purpose, function, and nonprofit status of this organization and the exempt status for Federal income tax purposes have not changed during preceding 12 months.

10. Extent and Nature of Circulation

$\begin{array}{lcc}\text { A. Total copies printed } & 2,816 & 2,753 \\ \text { B. Paid Circulation } & & \\ \quad \text { 1. Dealers, counter sales } & 0 & 0 \\ \text { 2. Mail subscriptions } & 2,502 & 2,510 \\ \text { C. Total paid circulation } & 2,502 & 2,510 \\ \text { D. Free distribution } & 12 & 12 \\ \text { E. Total distribution } & 2,514 & 2,524 \\ \text { F. Copies not distributed } & 302 & 229 \\ \text { G. Total } & 2,816 & 2,753\end{array}$

I certify that the statements made by me above are correct and complete-Samuel Albrecht, Executive Vice President.
} 